\title{
RADIONUCLIDE DETECTION LIMITS REQUIRED TO ESTIMATE HEALTH EFFECTS IN CERCLA RISK ASSESSMENT (U)
}

by D. M. Hamby

WSRC-TR--92-544

Westinghouse Savannah River Company

DE93 009892

Savannah River Site

Aiken, South Carolina 29808

Other Authors:

This paper was prepared in connection with work done under Contract No. DE-AC09-89SR18035 with the U. S. Department of Energy. By acceptance of this paper, the publisher and/or recipient acknowledges the U.S. Government's right to retain a nonexclusive, royalty-free license in and to any copyright covering this paper, along with the right to reproduce and to authorize others to reproduce all or part of the copyrighted paper.

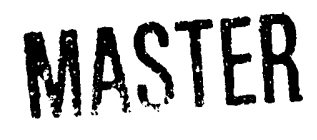




\section{DISCLAIMER}

This report was prepared as an account of work sponsored by an agency of the United States Government. Neither the United States Government nor any agency thereof, nor any of their employees, makes any warranty, express or implied, or assumes any legal liability or responsibility for the accuracy, completeness, or usefulness of any information, apparatus, product, or process disclosed, or represents that its use would not infringe privately owned rights. Reference herein to any specific commercial product, process, or service by trade name, trademark, manufacturer, or otherwise does not necessarily constitute or imply its endorsement, recommendation, or favoring by the United States Government or any agency thereof. The views and opinions of authors expressed herein do not necessarily state or reflect those of the United States Government or any agency thereof.

This report has been reproduced directly from the best available copy.

Available to DOE and DOE contractors from the Office of Scientific and Technical Information, P.O. Box 62, Oak Ridge, TN 37831; prices available from (615) 576-8401, FTS 626-8401.

Available to the public from the National Technical Information Service, U.S. Department of Commerce, 5285 Port Royal Rd., Springfield, VA 22161. 
Ẅis̄êC-TR-Y2-544

\title{
RADIONUCLIDE DETECTION LIMITS REQUIRED TO ESTIMATE HEALTH EFFECTS IN CERCLA RISK ASSESSMENTS
}

\author{
David M. Hamby bark \\ Westinghouse Savannah River Company \\ November 24, 1992
}
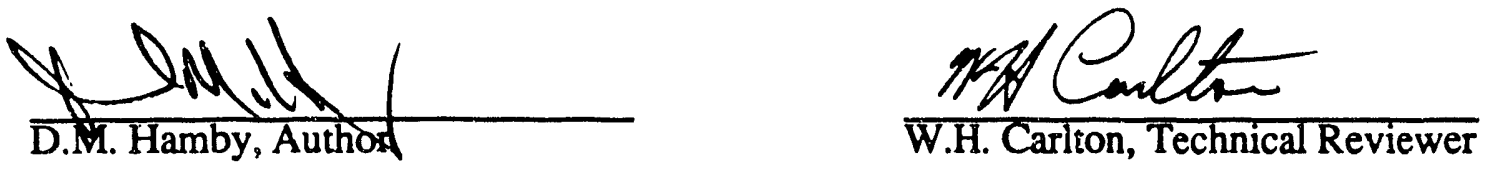

\section{INTRODUCTION}

Lower limits of detection (LLDs) have been calculated for radionuclides of environmental and ecological interest. The detection limits are risk-based and were derived using a methodology similar to that described by the Environmental Protection Agency for determining Preliminary Remediation Goals (PRGs) [EPA 1991]. PRGs, and the LLDs calculated in this report, are calculated assuming a risk level of $10^{-6}$, the risk deemed acceptable by the EPA.

LLDs have been calculated for radionuclides in water and soil. Water concentrations are based on risks resulting from the consumption of drinking water while soil concentrations are based on risks from incidental soil ingestion and external radiation exposure from ground surface contamination.

Water/soil concentrations are given in Table 1 for the requested radionuclides. Four radionuclides ( $\mathrm{Pb}-210, \mathrm{Ac}-228, \mathrm{Th}-228$, and $\mathrm{Th}-230)$ have been added to the list since they are daughter products in either the natural thorium decay series (Th-232) or the natural uranium decay series (U-238). Concentrations in the table are those that would result in a $10^{-6}$ risk to individuals exposed to radionuclides via the pathways described above.

Detection limits for "gross alpha" and "gross beta" are meaningless unless the assumption is made that the contamination is always made up of the same constituents. Furthermore, these measurements are generally for screening purposes and would not be of acceptable quality for most CERCLA activities. 


\section{RADIONUCLIDES IN WATER}

Water Consumption. The detection limits for radionuclides in water samples are calculated using,

$$
\mathrm{LLD}_{\mathrm{i}}^{\mathrm{w}}[\mathrm{pCi} / \mathrm{mL}]=\frac{\mathrm{Risk}}{\mathrm{CR}[\mathrm{L} / \mathrm{d}] \cdot 1000[\mathrm{~mL} / \mathrm{L}] \cdot \mathrm{SF}_{\mathrm{i}}^{\text {ing }}[\mathrm{risk} / \mathrm{pCi}] \cdot \mathrm{EF}[\mathrm{d} / \mathrm{yr}] \cdot \mathrm{ED}[\mathrm{yr}]}
$$

where CR is the water consumption rate, $S F_{i}^{i n g}$ is the ingestion slope factor for nuclide $i$, EF is the exposure frequency, and ED is the exposure duration. "Slope factors" are nuclide-specific risk/dose factors and are provided by EPA [1992]. A standard consumption rate of $2 \mathrm{~L} / \mathrm{d}$ has been used to calculate LLDs. It is further assumed that the individual is exposed for a period of 30 years $(E D)$ with a frequency of 350 days per year (EF). These assumptions are consistent with the future resident scenario which generally dominates a given risk assessment. For consistency with EPA guidance [EPA 1989], radioactive decay over the 30 year exposure period is not considered.

\section{RADIONUCLIDES IN SOIL}

Soil Ingestion. Detection limits, based on ingestion, for radionuclides in soil are given by,

$$
\operatorname{LLD}_{\mathrm{i}}^{\mathrm{s}}[\mathrm{pCi} / \mathrm{g}]=\frac{\mathrm{Risk}}{\mathrm{IR}[\mathrm{g} / \mathrm{d}] \cdot \mathrm{SF}_{\mathrm{i}}^{\mathrm{ing}}[\mathrm{risk} / \mathrm{pCi}] \cdot \mathrm{EF}[\mathrm{d} / \mathrm{yr}] \cdot \mathrm{ED}[\mathrm{yr}]}
$$

where IR is the incidental soil ingestion rate; the other variables were described above. The EPA [EPA 1989] has determined that the soil ingestion rate for children (ages 0 to 6) is $0.2 \mathrm{~g} / \mathrm{d}$ and $0.1 \mathrm{~g} / \mathrm{d}$ for adults. It is assumed that soil ingestion occurs for a period of 30 years. A weighted average ingestion rate $(0.12 \mathrm{~g} / \mathrm{d})$ has been used here to account for 6 years of intake at a rate of $0.2 \mathrm{~g} / \mathrm{d}$ and 24 years at a rate of $0.1 \mathrm{~g} / \mathrm{d}$.

External Exposure to Ground Surface Radionuclides. Detection limits for radionuclides in soil resulting in a risk of $10^{-6}$ from external exposure are given by,

$$
\mathrm{LLD}_{\mathrm{i}}^{e}[\mathrm{pCi} / \mathrm{g}]=\frac{\mathrm{Risk} \cdot 8760[\mathrm{hr} / \mathrm{yr}]}{\mathrm{ET}[\mathrm{hr} / \mathrm{d}] \cdot \mathrm{SF}_{\mathrm{i}}^{\mathrm{ext}}[\mathrm{risk} / \mathrm{yr} \mathrm{per} \mathrm{pCi} / \mathrm{g}] \cdot \mathrm{EF}[\mathrm{d} / \mathrm{yr}] \cdot \mathrm{ED}[\mathrm{yr}]}
$$

where ET is the exposure time $(1 \mathrm{hr} / \mathrm{d})$ and $\mathrm{SF}_{\mathrm{i}}^{\text {ext }}$ is the external exposure slope factor; the other variables are defined above. The external exposure slope factor is given in units of risk/yr per $\mathrm{pCi} / \mathrm{g}$. Therefore, a calculation is made of the equivalent number of years that the inividual is assumed to be exposed to ground surface contamination in units of activity per mass of soil. The LLD for radionuclides in soil is the lower of the two concentrations calculated for soil ingestion and external exposure. 
Table 1. CERCLA Risk-Based Radionuclide Detection Limits

Pisk Lovo! - 1E \&

\begin{tabular}{|c|c|c|c|}
\hline \multirow[b]{2}{*}{ Nuclide } & \multicolumn{3}{|c|}{ Detection Limits } \\
\hline & $\begin{array}{l}\text { Water } \\
\text { (pCi/mL) }\end{array}$ & $\begin{array}{c}\text { Soil (ingestion) } \\
(\mathrm{pCi} / \mathrm{g})\end{array}$ & $\begin{array}{c}\text { Soil (external) } \\
\text { (pCi/g) }\end{array}$ \\
\hline $\mathrm{H}-3$ & $8.8 E-01$ & $1.5 E+04$ & \\
\hline C-14 & 5.3E-02 & $8.8 E+02$ & \\
\hline$K-40$ & $4.3 E-0.3$ & $7.2 E+01$ & $1.5 E+00$ \\
\hline Co-60 & $3.2 E-03$ & $5.3 E+01$ & $9.7 E-02$ \\
\hline Sr-89 & $1.6 E-02$ & $2.6 E+02$ & $1.8 E+03$ \\
\hline Sr-90 & $1.4 \mathrm{E}-03$ & $2.4 E+01$ & \\
\hline$Y-90$ & $1.5 E-02$ & $2.5 E+02$ & \\
\hline TC.99 & $3.7 E-02$ & $6.1 E+02$ & $1.4 E+06$ \\
\hline$R u-106$ & 5.0E-03 & $8.4 E+01$ & \\
\hline Sb-125 & 5.7E-02 & $9.4 E+02$ & 7.0E-01 \\
\hline 1.129 & $2.5 E \cdot 04$ & $4.2 E+00$ & $2.0 E+02$ \\
\hline Cs-134 & $1.2 E-03$ & $1.9 E+01$ & $1.6 E-01$ \\
\hline Cs-137" & $1.7 E-03$ & $2.8 E+01$ & 4.2E-01 \\
\hline Eu-152 & 2.3E-02 & $3.8 E+02$ & 2.3E-01 \\
\hline Eu-154 & 1.6E-0? & $2.6 E+02$ & $2.0 E-01$ \\
\hline Eu-155 & $1.1 E-01$ & $1.8 E+03$ & $1.4 E+01$ \\
\hline $\mathrm{Pb}-210 t$ & $9.3 E-05$ & $1.6 E+00$ & $6.4 E+03$ \\
\hline $\mathrm{Ra}-226$ & $4.0 \mathrm{E}-04$ & $6.6 E+00$ & $7.0 E+01$ \\
\hline $\mathrm{Ra}-228$ & $4.8 E-04$ & $7.9 E+00$ & \\
\hline$A C-228 \dagger$ & $9.5 E-02$ & $1.6 E+03$ & 2.9E-01 \\
\hline Th-228t & 4.3E-03 & $7.2 E+01$ & $1.5 E+03$ \\
\hline Th-230t & $3.7 E-03$ & $6.1 E+01$ & $1.5 E+04$ \\
\hline Th-232t & 4.0E-03 & $6.6 E+01$ & $3.2 E+04$ \\
\hline$U-233$ & $3.0 E-03$ & $5.0 E+01$ & $2.0 E+04$ \\
\hline$U-234$ & $3.0 E-03$ & $5.0 E+01$ & $2.8 E+04$ \\
\hline$U-235$ & 3.0E-03 & $5.0 E+01$ & $3.5 E+00$ \\
\hline U-238t & $3.0 E-03$ & $5.0 E+01$ & $4.0 E+04$ \\
\hline$N p-237$ & $2.2 E-04$ & $3.6 E+00$ & 1.1E+02 \\
\hline $\mathrm{Pu}-238$ & $2.2 E-04$ & $3.6 E+00$ & $3.0 E+04$ \\
\hline Pu-239 & $2.1 E-04$ & $3.5 E+00$ & $4.9 E+04$ \\
\hline$P u-240$ & $2.1 E-04$ & $3.5 E+00$ & $3.1 E+04$ \\
\hline$P u-242$ & $2.2 E-04$ & $3.6 E+00$ & $3.6 E+04$ \\
\hline$A m-241$ & 2.0E-04 & $3.3 E+00$ & $1.7 E+02$ \\
\hline$A m-243$ & 2.0E-04 & $3.3 E+00$ & $3.5 E+01$ \\
\hline $\mathrm{Cm}-243$ & 2.5E-04 & $4.2 E+00$ & $5.2 E+00$ \\
\hline $\mathrm{Cm}-244$ & 3.0 E- 04 & $5.0 E+00$ & $2.8 E+04$ \\
\hline $\mathrm{Cm}-245$ & $2.0 E-04$ & $3.3 E+00$ & $1.6 E+01$ \\
\hline $\mathrm{Cm}-246$ & 2.0E-04 & $3.3 E+00$ & $3.1 E+04$ \\
\hline $\mathrm{Cm}-247$ & $2.2 E-04$ & $3.6 E+00$ & 9.1E-01 \\
\hline $\mathrm{Cm}-248$ & $5.2 E-05$ & 8.7E-01 & $3.8 E+04$ \\
\hline
\end{tabular}

includes ganma emissions from Ba-137m.

tin natural uranium (U-238) or thorium (Th-232) decay series. 


\section{REFERENCES}

[EPA 1989] Environmental Protection Agency, "Risk Assessment Guidance for Superfund: Volume 1 - Human Health Evaluation Manual (Part A)", EPA/540/1-89/002, Washington, DC, December 1989.

[EPA 1991] Environmental Protection Agency, "Risk Assessment Guidance for Superfund: Volume 1 - Human Health Evaluation Manual (Part B, Development of Risk-based Preliminary Remediation Goals)", 9285.701B, Washington, DC, December 1991.

[EPA 1992] Environmental Protection Agency, "Health Effects Assessment Summary Tables", OERR 9200.6-303(92-1), Washington, DC, March 1992. 

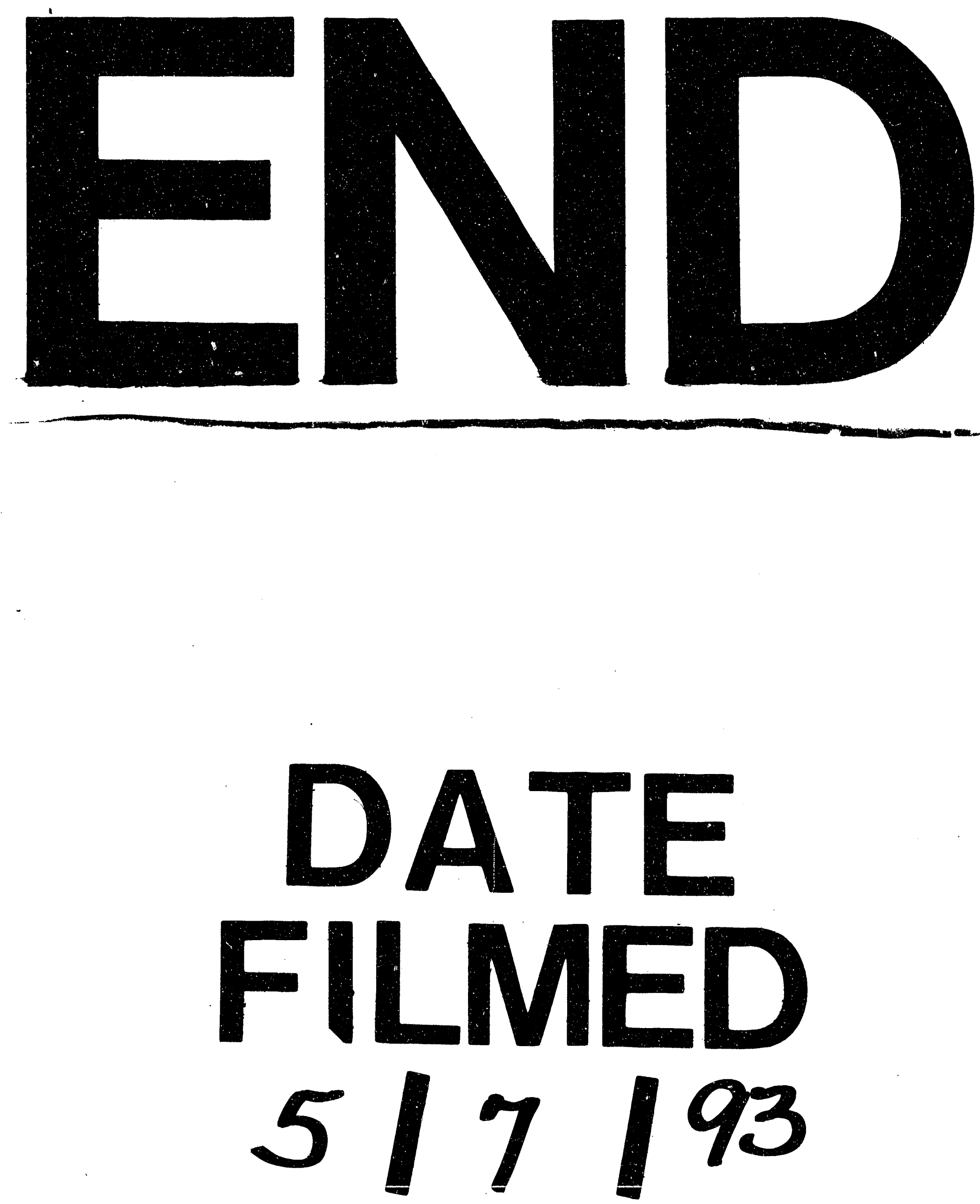
